\title{
Otoritas Wali Nikah Dalam Islam: Analisis Perkawinan Tanpa Wali di Indonesia Perspektif Fiqh dan Hukum Positif
}

\author{
Fathonah K. Daud \\ IAI Al Hikmah Tuban \\ E-mail: fathkasuwi@gmail.com \\ Ramdani Wahyu Sururuie \\ UIN Sunan Gunung Djati Bandung \\ ramdaniwahyusururie@uinsgd.ac.id
}

\begin{abstract}
Abstrak: Tulisan ini menganalisis tentang hukum perkawinan seorang perempuan tanpa wali dalam kajian fiqh dan Hukum Positif di Indonesia. Metode penulisan artikel dengan pendekatan library research. Adapun hasil dari tulisan ini menemukan bahwa pernikahan perempuan tanpa wali menurut hukum positif di Indonesia adalah tidak sah. Meskipun telah ditemukan adanya pendapat dari mazhab Hanafi dan Syiah Imamiyah bahwa perempuan dewasa dan berakal sehat diperbolehkan menikahkan dirinya sendiri dengan catatan bahwa calon lelakinya adalah sederajat (sekufu). Apabila tidak sekufu, wali berhak memaksa anak perempuannya. Namun, karena produk hukum di Indonesia adalah menganut mazhab Syafi'i, maka hukum perempuan yang menikah tanpa wali adalah dipandang batal. Hal ini berdasarkan argumentasi mazhab Syaf'i yang berlandaskan kepada hadits Nabi saw yang sangat popular, "tidak sah pernikahan tanpa wali”. Adapun bagi perempuan yang tidak punya wali atau walinya adhal, maka menggunakan wali hakim. Mazhab Maliki, Mazhab Syfi'i dan Mazhab Hanbali tidak membenarkan seorang perempuan, gadis atau janda, menikahkan dirinya sendiri.
\end{abstract}

Kata Kunci: Pernikahan tanpa wali, hukum positif Indonesia, fiqh

\begin{abstract}
This paper analyzes the marriage law of a woman without aguardian in the study of fiqh and positive law in Indonesia. The method of writing articles with a library research approach. The results of this paper find that the marriage of women without a guardian according to positive law in Indonesia is invalid. Although it has been found that there are opinions from the Hanafi and Shia mazhab that mature and reasonable women re allowed to marry themselves provided that the prospective male is equel (sekufu). If not equel, the guardian has the right to force his daughter. However, because the legal product in Indonesia is to adhere to the Shafi'i school, the law foe women who marry without a guardian is considered null and void. This is based on the argument of the Shafi'i mazhab which is based on the very popular hadith of the Prophet, "marriage without a guardian is not valid". As for women who do not have a guardian or adhal guardian, then they use a judge's guardian. The Maliki mazhab, the Shafi'i mazhab and the Hanbali mazhab do not allow a women, girl or widow to marry herself.
\end{abstract}

Keyword: Msrriage without a guardian, Indonesia positive law, fiqh 


\section{Pendahuluan}

Di era modern ini persoalan wali kadang menjadi hambatan bagi seorang perempuan yang hendak menikah dengan calon pendamping pilihannya, hanya karena faktor tidak disetujui oleh orang tuanya. Keadaan ini kadang menjadi persoalan serius, dan jalan penyelesaian yang sering ditempuh adalah ayah (apabila masih ada) kemudian dianggap telah menjadi wali adhal, melalui putusan pengadilan. Namun, bagaimana sebenarnya hukum Islam menghadapi kasus, misalnya, ada perempuan yang kemudian menikahkan dirinya sendiri?

Pembahasan nikah tanpa wali sebenarnya masuk wilayah debatable dan bukanlah persoalan baru dalam kajian hukum Islam. Dalam fiqh sebenarnya sudah ada ulama yang memperbincangkan persoalan tersebut dan membolehkan seorang perempuan dewasa menikahkan dirinya. Namun, dalam buku karya Syafiq Hasyim (Hal-Hal yang Tak Terpikirkan tentang Isu-Isu Keperempuanan dalam Islam) termasuk buku karya Masdar F. Mas'udi (Islam dan Hak-Hak Reproduksi Perempuan), misalnya sempat menuai kritik dan menjadi polemic di awal terbitnya. Dimana buku tersebut telah menjelaskan bahwa perempuan dewasa dan berakal sehat dipandang mampu dan boleh menikahkan dirinya sendiri, alias tidak perlu wali. ${ }^{1}$

Persoalan tersebut apabila berkaca kepada produk hukum-hukum yang ada dan telah menjadi landasan pernikahan mayoritas Muslimin di Indonesia yang dikemas dalam mazhab Syafi'i, tentu akan menjadi problematis. Telah difahami, bahwa mazhab Syafi'i dikenal sangat berhati-hati dalam menetapkan suatu hukum. Dalam pandangan mazhab Syafii, kehadiran dan persetujuan wali adalah penting, karena wali termasuk dalam syarat atau rukun nikah yang harus dipenuhi. ${ }^{2}$ Apabila perempuan menikahkah dirinya secara otomatis hukum pernikahannya dipandang tidak sah.

Dalam persoalan menikah, sebenarnya siapa yang lebih berhak menentukan atau memilih atas calon pasangan hidup setiap individu, seseorang yang hendak menikah itu sendiri atau orang tua (ayah)nya? Pembahasan ini kelihatannya sudah tuntas dibahas dalam fiqh, namun persoalan wali masih saja timbul di era sekarang ini dengan berbagai faktor yang berbeda, dan perlu kiranya mendapatkan jawabannya.

Ada satu hal yang benar-benar sering menjadi sorotan tajam ketika seseorang hendak menikah, misalnya terkait memilih pasangan atau sebelum lamaran, ada perbedaan mencolok

\footnotetext{
${ }^{1}$ Wardatun Nabilah, 'Metode Penetapan Hukum Masdar F. Mas'udi dan Syafiq Hasyim tentang Wali Nikah Perempuan', (Surabaya, 2014), Skripsi IAIN Sunan Ampel Surabaya.

2 Tihami dan Sahrani, Sohari, 'Fikih Munakahat'(Jakarta : Rajawali Press, 2009), 12
} 
antara anak putra dan anak putri. Apabila seorang anak putra telah mencapai usia akil baligh, ia sudah dewasa dan akalnya sehat, maka ia bebas untuk memilih pasangannya, dan tak seorang pun yang berhak memaksanya. Namun pendapat fiqh yang berkaitan dengan anak putri, ada perbedaan. Apabila keadaannya menjanda dan ingin menikah, ketentuan fiqhnya, tidak ada seorang pun yang berhak mencampuri urusannya, meskipun kehadiran wali dalam pernikahannya masih diperlukan. Tetapi apabila anak putri tersebut seorang gadis dan hendak menikah, setidaknya menurut fiqh Indonesia umumnya, harus mendapat persetujuan ayah (wali)-nya. Dalam perspektif fiqh mazhab Syafi'i, ayah berhak mendesak putri gadisnya untuk menikah dengan calon suami pilihan ayahnya. ${ }^{3}$ Di samping itu kehadiran wali dalam pernikahan anak perempuannya adalah signifikan dalam fiqh Syafi'i, sehingga suatu pernikahan dipandang tidak sah tanpa (kehadiran) walinya. ${ }^{4}$ Karena kehadiran wali termasuk dalam salah satu syarat, atau ada yang mengatakan bagian dari rukun, pernikahan. Hal ini berdasarkan hadits berikut ini: 'Tidak sah pernikahan kecuali dengan wali' ${ }^{5}$

Persoalan ini mendapatkan kritik di era modern, sebab para perempuan kini sudah banyak yang mandiri secara ekonomis dan berpendidikan. Mestinya sama saja, bahwa tiada seorang pun, termasuk ayahnya, yang boleh memaksa gadis yang cukup umur dan berakal sehat untuk menikah dengan seorang lelaki tanpa kerelaan hatinya. Persolannya, bagaimana sebenarnya perbincangan nikah tanpa wali ini dalam pandangan ulama mazhab empat dan juga hukum positif? Bolehkan perempuan menikah tanpa wali? Tulisan ini akan mencoba mengkaji dan mencari jawaban persoalan tersebut dengan berdasarkan kepada dasar-dasar hukumnya yang menjadi sumber dalam Islam.

Artikel ini adalah kajian yuridis-normatif. Metode penelitian artikel ini adalah kajian literature (library research), yakni dengan meneliti literatur-literatur dan undang-undang yang terkait dengan tema hukum wali nikah baik dalam fiqh maupun dalam hukum positif di Indonesia dan dipaparkan dalam bentuk deskriptif-komparatif. Metode ini merupakan rentetan kegiatan pengumpulan data pustaka, melalui kajian terhadap tema-tema yang serupa, diteliti, dicatat dan kemudian diolah dengan menggunakan literature review. Selanjutnya dianalisis secara mendalam dengan pendekatan filsafat hukum terkait hukum dan urgensi keberadaan wali dalam pernikahan di Indonesia.

\footnotetext{
${ }^{3}$ Al-Syairâzî, Abî Ishâq Ibrâhîm bin c'Alî bin Yûsuf al-Fairuzzâbâdî, al-Muhadzdzab fî Fiqh al-Imâm al-Syâficî, (Damascus: Dâr al-Qalam, 1992), juz 2, 429-430

${ }^{4}$ Ibnu Majah, Sunan Ibn Majah, (Riyad: Dar al-Salam, 2008), no. 1880, 2589

${ }^{5}$ HR. Abû Daud no. 2085, Tirmidzi no. 1101, Ibnu Majah no. 1880 dan Ahmad 4:418; shahih; Al-Jaziry, ${ }^{c}$ Abd al-Rahman, Kitab al-fiqh ${ }^{c}$ Ala al-Madzahib al-Arbac $a h$....., 46
} 


\section{PEMBAHASAN}

\section{Pengertian Wali Nasab}

Secara bahasa, kata 'wali' dari bahasa Arab, waly atau perwalian (الولاية), bentuk muannatsnya al-waliyyah dan pluralnya al-auliya' (الأولياء), mempunyai arti teman karib, mencintai, sekutu, yang menolong, pengasuh atau orang yang menguruskan perkara seseorang. Kata 'wali' disebut dalam al-Qur'an sebanyak 44 kali dan kata auliya' disebut sebanyak 22 kali. Pengertian perwalian antaranya, الولاية في اللغة تأتي بمعنى المحبة والنصرة perwalian dalam bahasa berarti cinta dan pertolongan). ${ }^{6}$

Namun, penggunaan kata wali dan auliya' berbeda-beda. Demikian juga, definisinya berbeda-beda sesuai konteks kata yang dipergunakan. Dalam kamus besar bahasa Indonesia 'wali' berarti orang yang menurut hukum (agama, adat) diserahi kewajiban mengurus anak yatim serta hartanya, sebelum anak itu dewasa. ${ }^{7}$ Adapun dalam terminologi fuqaha, wali adalah otoritas seseorang untuk melaksanakan suatu perbuatan secara langsung tanpa harus terlebih dahulu mendapat perizinan orang lain. ${ }^{8}$ Pengertian yang lain, الولاية في الشرع هي تنفيد

(perwalian secara syara' bermakna pelaksanaan perkataan pada orang lain dan pengawasan atas urusannya. ${ }^{9}$

Berdasarkan pengertian tersebut, Islam telah menetapkan ayah sebagai wali bagi anakanaknya. Tetapi maksud dalam perbincangan di sini adalah dalam hukum perkawinan, fungsi wali di sini sebagai wali nasab. Dalam hal ini dikarenakan ayah merupakan orang yang paling dekat, yang di samping mempunyai hubungan darah, ayahlah yang bertanggungjawab atas keperluan hidup anak-anaknya, ayahlah yang mengawasi dan menguruskan segala urusan anak-anaknya selama ini sejak mereka lahir hingga mereka dewasa atau menikah.

Islam menetapkan tanggungjawab wali sangat besar terhadap orang-orang yang di bawah perwaliannya. Seperti menolongnya, mencukupi keperluannya, mengawasinya dan

\footnotetext{
${ }^{6}$ Mustafa al-Khin dan Mustafa al-Bugha, Al-Fiqh al-Manhaji 'ala Mazhab al-Imam al-Syafi'I, (Surabaya: Al-Fithrah, 2000), Juz IV, 60

${ }^{7}$ Departemen Pendidikan Nasional, Kamus Besar Bahasa Indonesia, (Jakarta: Balai Pustaka, 2001), Edisi III, 1267

${ }^{8}$ Summa, Muhammad A., Hukum Keluarga Islam di Dunia Islam, (Jakarta: PT Raja Grafindo Persada, 2005), 134-135

${ }^{9}$ Mustafa al-Khin dan Mustafa al-Bugha, Al-Fiqh al-Manhaji 'ala Mazhab al-Imam al-Syafi'I, (Surabaya: Al- Fithrah, 2000), Juz IV, 60
} 
membiayainya. Apabila ayah tidak ada atau meninggal, maka perwalian akan beralih kepada orang terdekat atau kakeknya. Oleh demikian ada yang memberi pengertian wali dalam pernikahan adalah orang yang memiliki hak otoritas secara syar'i untuk menikahkan seseorang yang berada dalam perwaliannya, tanpa harus terikat persetujuan orang lain terlebih dahulu. $^{10}$

\section{Macam-Macam Wali}

Pembagian wali nikah oleh beberapa kalangan, sebagai berikut: ${ }^{11}$

1. Wali Nasab, yaitu orang yang memiliki hubungan darah dengan seorang putri yang akan menikah. Menurut Hanafiyah, wali nasab terdiri dari seluruh kerabat nasab dan seluruhnya mempunyai hak ijbar bagi perempuan yang belum cukup umur dan tidak waras akalnya. Sementara Malikiyyah berpendapat, bahwa wali nasab hanya terdiri dari kerabat nasab yang dapat menerima ashabah dalam warisan saja. Bahkan kedudukan anak lebih utama daripada ayah dan kakek. Hak ijbar hanya ada pada ayah saja.

Menurut Jumhur ulama wali nasab ada dua:

(i). Wali aqrâb (wali dekat): hanya ayah, tetapi apabila ayah berhalangan bisa digantikan oleh kakek. Wali di sini disebut wali mujbir, yang mempunyai hak untuk mengawinkan putri yang belum cukup umur dengan tanpa meminta persetujuannya.

(ii) Wali ab'ad (wali jauh): wali selain dari garis kerabat dari ayah, kakek, anak dan cucu.

Beberapa hal yang menyebabkan peralihan wali aqrâb kepada wali $a b^{\prime} a d$, adalah: ${ }^{12}$

a. Wali aqrab belum dewasa

b. Wali aqrab non-Muslim

c. Wali aqrab fasik

d. Wali aqrab gila

e. Wali aqrab tuli atau bisu

f. Wali Hakim

\footnotetext{
${ }^{10}$ Ismatilah dkk, Makna Wali dan Auliya'dalam al-Qur'an, Diya' al-Afkar, Vol. 4, no. 02 Desember, 2016,

${ }^{11}$ Amir syarifuddin, Hukum Perkawinan...., 75

${ }^{12}$ Tihami dan Sohari Sahrani, Fikih Munakahat: Kajian Fikih Nikah Lengkap. (Jakarta: Rajawali Press, 2009$), 97$
} 


\section{Kedudukan Wali Nikah dalam Pandangan Empat Mazhab}

Sebagaimana definisi wali di atas, bahwa wali nikah diartikan sebagai seorang yang mengatas nama pengantin putri dalam suatu akad nikah, atau bertindak atas nama orang yang dimintai persetujuannya untuk kelangsungan pernikahan tersebut. Pada umumnya, akad nikah di Indonesia dilakukan oleh pengantin putra itu sendiri dan pengantin putri yang diwakili oleh walinya. Di Indonesia, kebanyakan pengantin perempuan tidak dihadirkan dalam meja akad yang sama dengan pengantin laki-laki. Menurut jumhur ulama, antara rukun nikah yaitu harus ada wali. Oleh itu, wali harus ada pada saat pernikahan berlangsung. Tanpa wali sebuah pernikahan dihukumi tidak sah. Terutama bagi pernikahan mereka yang belum mukallaf. ${ }^{13}$

Namun, pembahasan tentang wali nikah ini sebenarnya merupakan bagian dari ikhtilaf para imam mazhab. Di antara ulama ini ada perbedaan pandangan dalam hukum wali dalam pernikahan. Penjelasan terkait pandangan ulama mazhab akan diuraikan di bawah ini:

\section{Pendapat Hanafi}

Dalam hal perwalian pernikahan bagi perempuan yang sudah baligh dan berakal, termasuk janda, wali tidak menjadi syarat sahnya pernikahan. Wali tidak dapat memaksa putrinya yang baligh dan berakal untuk menikah tanpa persetujuannya. Imam Abu Hanifah memandang sah pelaksanaan pernikahan tanpa wali, baik perempuan dewasa menikah secara mandiri atau meminta kepada orang lain, bukan wali nasab, untuk menikahkannya. 14

Pendapat yang demikian itu tidak berdasarkan logika semata, tetapi telah didasarkan kepada dalil-dalil yang dipandang otoritatif.

Pertama, Dalam pandangan mazhab Hanafi, perempuan itu adalah manusia yang juga memiliki ahliyyah yang sempurna, sama seperti laki-laki, sehingga ia berhak melakukan tasharruf secara mandiri dalam harta. Maka sudah seharusnya perempuan juga memiliki hak melakukan akad dalam perkawinan terhadap dirinya.

Antara dalil otoritatifnya bersumber dari surat al-Baqarah [2]: 230 dan 232:

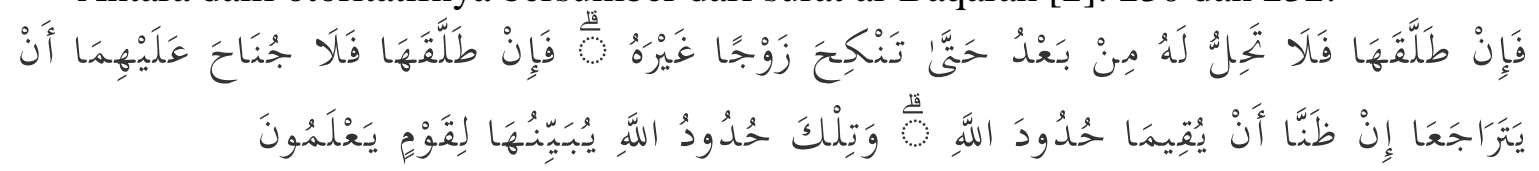

Artinya: 'Jika suami mentalaknya (sesudah talak yang kedua), maka perempuan itu tidak lagi halal baginya hingga ia kawin dengan suami yang lain. kemudian apabila suami yang baru itu telah menceraikannya. Maka tidak ada dosa bagi keduanya (bekas suami pertama dan istri) untuk menikah kembali jika keduanya

\footnotetext{
${ }^{13}$ Tihami dan Sohari Sahrani, Fikih Munakahat: Kajian Fikih Nikah Lengkap....., 99

${ }^{14}$ Syaiful Hidayat, Wali Nikah dalam Perspektif Empat Mazhab, Inovatif, vol. 2 no.1, Februari, 2016, 109
} 
berpendapat akan mampu menjalankan hukum-hukum Allah. Itulah hukumhukum Allah diterangkannya kepada kaum yang (mau) mengetahui' (Q.S alBaqarah [2]: 230)

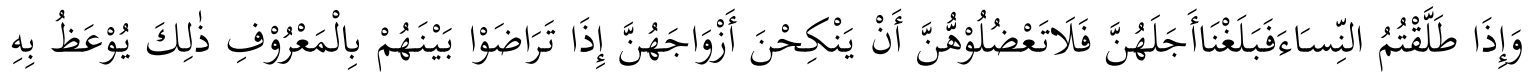

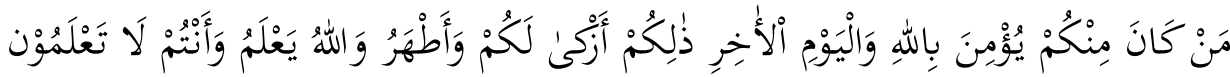

Artinya: 'Apabila kamu menceraikan istri-istrimu, lalu habis masa iddah-nya, maka janganlah kamu menghalangi mereka nikah lagi dengan calon suaminya, apabila telah terdapat kerelaan di antara mereka dengan cara yang ma'ruf. Itulah yang dinasehatkan kepada orang-orang yang beriman diantara kamu kepada Allah dan hari akhir. Itu lebih baik bagimu dan lebih suci. Allah Maha Tahu sedang kamu tidak mengetahui' (Q.S Al-Baqarah [2]: 232)

Berdasarkan ayat di atas, ulama Hanafiyah berpendapat sebagai berikut:

(a). Penghalangan dalam ayat di atas belum tentu hanya ditujukan kepada para wali, mungkin juga kepada pasangan suami istri atau kemungkinan lain ditujukan kepada orang-orang yang mukmin yang umum.

(b). Makna ayat tersebut ditujukan kepada orang yang berakal atau lainnya, seperti kerabat dekat perempuan yang bercerai. Intinya ayat ini tidak menunjuk wali secara mutlak. ${ }^{15}$

Kedua, Berdasarkan kepada petunjuk Hadits yang menyatakan bahwa perempuan itu lebih berhak atas dirinya sendiri, daripada orang lain. Apabila seorang wali hendak menikahkannya dengan seorang lelaki pilihan walinya, maka harus atas persetujuan dari anak perempuan tersebut. Hal ini berdasarkan pada beberapa Hadits, yang terdapat perbedaan redaksi. Antara lain sebagai berikut:

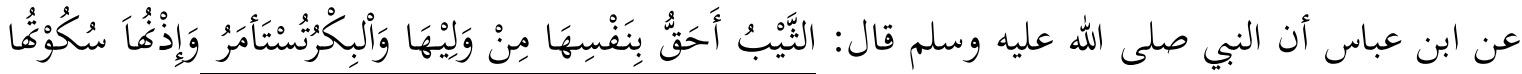
(ر) (ر) (ر)

Artinya: 'Janda lebih berhak atas dirinya daripada walinya dan gadis dimintai persetujuannya dan persetujuannya adalah diamnya'.

Menurut mazhab Hanafi, perempuan (gadis atau janda) memiliki hak dalam melakukan akad. Sedangkan wali hanya berhak melakukannya atas persetujuan anak perempuannya. ${ }^{16}$ Pendapat ini sama dengan pendapat Abu Yusuf, berdasarkan Hadits berikut ini:

(وينعقد نكاح الحرة العاقلة البالغة برضاها) وإن لم يعقد عليها ولي بكرا كانت أوثيبا عند أبي حنيفة وأبي يوسف رمهما الله......

\footnotetext{
${ }^{15}$ Al-Jaziry, 'Abd al-Rahman, 1990, Kitâb al-fiqh 'Alâ al-Madzâhib al-Arbacah (Bairut: Dâr al-Kutub al-Ilmiyah), Jil. 4, 4849

${ }^{16}$ Ibid., 49
} 
Artinya: Pernikahan perempuan yang merdeka, berakal, baligh dengan kerelaannya adalah terlaksana sah, meskipun walinya bukan orang yang melakukan akad, perempuan tersebut gadis atau janda. Ini menurut Abu Hanifah dan Abu Yusuf....

Pernyataan hadits di atas menjelaskan bahwa tasharruf perempuan yang merdeka dan baligh ini dalam pernikahan sama dengan dalam hal masalah harta benda. Perempuan yang demikian bisa membeli dan menjual sesuatu dengan sendirinya. Maka dalam pernikahan juga dipandang ia berhak untuk memilih calon suaminya.

Namun, apabila pernikahannya tersebut dilakukan dengan seseorang yang tidak sepadan (sekufu), maka wali dipandang berhak untuk melakukan penentangan atau mengajukan keberatan. Meskipun demikian, penentangan atau pemisahan tersebut hanya bisa dilakukan berdasarkan putusan hakim. Pendapat ini seirama dengan pendapat Imam al-Syaibani berikut ini: ${ }^{17}$

وإذا زوجت المرأة نفسها غير كفءفلأولياء أن يفرقوا بينها وبينه.لايكون ذلك إلاعند قاض. وأيهماما مات قبل الفرقة فان الباقي يرثه.... - مر

Artinya: Apabila seorang perempuan menikahkan dirinya sendiri dengan orang yang tidak sepadan (kufu) dengannya, maka bagi walinya boleh memisahkan keduanya. Hal tersebut (memisahkan keduanya) tidak terjadi kecuali berdasarkan keputusan hakim. Siapapun antara keduanya yang meninggal sebelum terjadi perpisahan, maka pihak yang masih hidup dapat mewarisi hartanya....

Pemahaman seperti itu juga dapat dibenarkan apabila perempuan yang dewasa dan berakal tersebut menyerahkan urusan perkawinannya kepada orang Muslim, sepanjang calon suaminya adalah sepadan (sekufu). Praktik ini kedudukannya dapat disamakan ketika perempuan menikahkan dirinya sendiri. ${ }^{18}$ Atas dasar pernyataan tersebut, menurut Imam Hanafi, hak ijbar wali tidak berlaku bagi perempuan dewasa, berakal dan janda. Seorang wali harus betul-betul meminta persetujuannya apabila hendak menikahkannya. Apabila perempuan tersebut tidak rela atas pernikahan tersebut, maka tidak dibenarkan pernikahan tetap berlangsung. Demikian juga dalam meminta persetujuan, untuk kasus gadis bisa mengikuti petunjuk hadits. Sementara untuk janda, persetujuannya adalah harus ada pernyataan yang tegas dan jelas.

Sedangkan dalam wali mujbir, mazhab Hanafi menetapkan, dapat diterapkan kepada beberapa orang berikut ini:

\footnotetext{
${ }^{17}$ Al-Syaibani, Hasan, Al-Aslu, (Qatar: Awqaf, 2012), juz 10, 198

${ }^{18}$ Al-Syaibani, Hasan, $A l-A s l u, \ldots ., 205$
} 
1. Anak yang belum dewasa.

Pendapat mazhab ini bahwa wali anak yang belum baligh adalah ayah kandungnya, sedangkan ibunya tidak mempunyai hak perwalian, dan semua ahli kerabat dekat yang laki-laki, seperti saudara laki-laki dan paman. ${ }^{19}$

2. Orang yang tidak berakal (gila)

Dalam fiqh, ulama tidak berbeda pendapat dalam memberi hukum orang gila yang sama dengan anak kecil. Baik gila sejak lahir maupun setelah baligh.

3. Orang idiot

Pernikahan safih (orang idiot) tidak sah, kecuali dengan izin walinya. Namun apabila seorang yang belum cukup usia hingga baligh dalam keadaan mumayyiz, kemudian baru mengalami idiot, maka perwaliannya diserahkan pada hakim saja, tidak pada ayah, kakeknya, juga bukan pada orang yang menerima wasiat dari ayah dan kakek.

4. Perempuan yang baligh, berakal sehat (Akil) atau janda.

Bagi perempuan yang dewasa dan akil diperbolehkan menentukan sendiri calon suaminya, juga dibenarkan apabila menikahkan dirinya meskipun tanpa wali dan tanpa dua orang saksi.

Seorang janda boleh menikahkan dirinya setelah memenuhi syarat-syarat berikut ini:

a. Sekufu. Apabila calon suaminya tidak sepadan, maka walinya mempunyai hak ijbar untuk mengajukan kepada qadi untuk membatalkan pernikahannya.

b. Maharnya tidak boleh kurang dari mahar misl. apabila kurang, maka wali mempunyai hak ijbar untuk membatalkannya melalui qadi. ${ }^{20}$

\section{Pendapat Maliki}

Menurut mazhab Maliki, wali masuk kategori dalam syarat sah nikah, nikah tanpa wali hukumnya batal. Hal ini karena semua urusan anak menjadi tanggungjawab ayahnya. Bahkan bagi pengikut mazhab Maliki, wali adalah masuk rukun pernikahan. ${ }^{21}$ Oleh itu, wali mempunyai hak ijbar terhadap anak-anak.

$$
\text { عن أبي بردة أبي موسى عن أبيه رضي الله عنهما قال: قال رسول الله صلى الله عليه وسلم لا نكاح إلا بولي }
$$

Artinya: Nabi bersabda: pernikahan dipandang tidak sah tanpa wali (HR. Ahmad, Imam Empat)

\footnotetext{
${ }^{19}$ Mughniyah, Muhammad Jawad, Fikih Lima Mazhab, 346

${ }^{20}$ Syaiful Hidayat, Wali Nikah dalam Perspektif Empat Mazhab, ....., 117-118

${ }^{21}$ Al-Jaziry, ${ }^{\mathrm{c}} \mathrm{Abd}$ al-Rahman, Kitâb al-fiqh ${ }^{c}$ Alâ al-Madzâhib al-Arbac $a h$....., 46
} 
Mazhab Maliki yang terkenal menjalankan tradisi Nabi ini, menetapkan hak ijbar wali dengan berdasarkan dari hadits. Meskipun demikian, Imam Malik menjelaskan hal tersebut berdasar kepada al-Qur'an, surat al-Baqarah, 232, dimana ayat ini juga digunakan dalil oleh mazhab Hanafiyyah dan ayat 221 berikut ini:

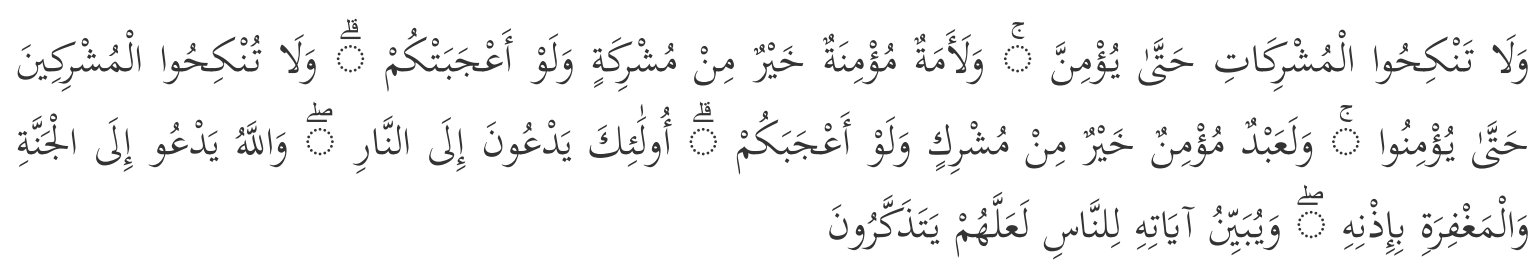

Artinya: 'Dan janganlah kamu menikahi perempuan-perempuan musyrik, sebelum mereka beriman. Sesungguhnya perempuan budak yang mukminah lebih baik dari perempuan yang musyrikah, walaupun dia menarik hatimu Dan janganlah kamu menikahkan orang-orang musyrik (dengan perempuan-perempuan mukmin) sebelum mereka beriman. Sesungguhnya budak yang mukmin lebih baik dari orang musyrik, walaupun ia menarik hatimu. Mereka mengajak ke neraka, sedangkan Allah mengajak ke surga dan ampunan dengan izin-Nya. Allah menerangkan ayat-ayat-Nya, kepada manusia supaya mereka mengambil pelajaran' (Q.S al-Baqarah [2]: 221)

Sementara hadits masyhur yang dijadikan dasar hukumnya adalah:

$$
\begin{aligned}
& \text { عن عائشة رضي الله عنها، قال رسول الله صلى الله عليه وسلم أيماإمرأة نكحت بغير إذن وليهافنكاحها باطل } \\
& \text { (أخرجه الأربعةإلا النسائ وصححه أبو عوانةوابن حبان والحكيم) }
\end{aligned}
$$

Artinya: Mana-mana perempuan yang menikah tanpa izin walinya, maka pernikahannya adalah batal. $^{22}$

$$
\begin{aligned}
& \text { عن أبي بردة أبي موسى عن أبيه رضي الله عنهما قال: قال رسول الله صلى الله عليه وسلم لانكاح إلا بولي } \\
& \text { (رواه أحمد و الأربعةإلا النسائ وصححه إبن المدنيي والترميذيوابن حبان) }
\end{aligned}
$$

Artinya: Perkawinan tidak dipandang sah kecuali ada wali.

Hadits di atas sungguh masyhur dan sering dijadikan dasar argumentasi keharusan adanya wali dalam pernikahan. Oleh demikian menurut mazhab Maliki, kehadiran dan keridaan wali saat pernikahan anak sangat dibutuhkan. Jadi hak ijbar wali di sini berbeda dengan pendapat Imam Abu Hanifah, yaitu diperbolehkan dan kedudukannya paling utama. Maka pelaksanaan pernikahan yang tidak ada walinya dipandang tidak sah.

Dalam Perwalian Imam Malik terdapat dua kategori:

Pertama, Wali ikhtisah (khusus). Perwalian ini hanya berlaku bagi orang-orang khusus saja. Seperti ayah, kakek atau pemimpin Negara.

Kedua, Wali amah (umum). Yaitu perwalian yan dimiliki oleh setiap orang Islam.

Secara jelasnya, mazhab Maliki memerinci hak ijbar wali sebagai berikut:

${ }^{22}$ Al-Asqalany, Ibnu Hajar, Bulugh al-Maram, 117 
1. Anak gadis yang berakal dan baligh, maka wali memiliki hak ijbar menikahkannya.

2. Perempuan janda. Di sini hak ada pada keduanya, yaitu pada perempuan janda dan walinya. Pernikahan janda tetap harus ada persetujuhan walinya. Demikian dalam pengucapan akad adalah menjadi hak ijbar wali dengan persetujuan mempelai perempuan. Mazhab Maliki memperbolehkan anak menikahkan ibunya, bahkan anak dipandang lebih utama daripada ayah.

Adapun orang-orang yang dinikahkan oleh wali mujbir adalah:

a. Anak kecil, walinya adalah ayah kandungnya saja, sebab kakek dalam pendapat mazhab Maliki tidak memiliki hak sebagai wali bagi cucunya. Demikian juga ibu, dalam pandangan mazhab Maliki tidak memiliki hak perwalian. Setelah itu baru orang-orang yang menerima wasiat dari ayahnya. Jika tidak ada, maka walinya jatuh ke tangan hakim. ${ }^{23}$

b. Orang tidak waras (hilang ingatan), di sini sama baik gila sejak kecil atau setelah baligh.

Menurut Imam Malik, hukum perwalian orang gila sama dengan hukum anak kecil.

c. Orang Idiot (Safih)

Mazhab Maliki sepakat bahwa wali berhak mengawinkan orang idiot. Tetapi pendapat Imam Maliki di sini berbeda dengan pendapat ulama mazhabnya, akad orang idiot adalah sah, maka tidak perlu minta persetujuan walinya.

d. Perempuan baligh, berakal sehat dan janda.

Di sini pendapat Malikiyyah, bahwa hak ijbar wali hanya berlaku bagi gadis, sedangkan janda tidak ada. Dalam hal ini keberadaan wali dalam pernikahan janda hanya untuk sahnya akad nikah saja. ${ }^{24}$ Imam Malik tidak memperbolehkan seorang perempuan, gadis atau janda, menikahkan dirinya sendiri.

\section{Pendapat Syafi'iyyah}

Dalam pandangan hukum wali dalam pernikahan, Imam Syafii telah menjelaskan dalam kitab Al-Umm tentang Hadits yang menceritakan kondisi Aisyah ketika menikah. Meskipun penulis masih menyangsikan redaksi hadits ini, karena ditemukan riwayah yang menceritakan sayyidah Aisyah menikah pada umur 14 tahun, bukan umur 6 tahun, dan

\footnotetext{
${ }^{23}$ Amir syarifuddin, Hukum Perkawinan Islam di Indonesia...75

${ }^{24}$ Ahmad Azhar, Hukum Perkawinan Islam, ....43
} 
baru dikumpuli oleh Nabi pada umur 17 tahun, setelah Aisyah hijrah ke Madinah, tetapi ini hanya untuk menyampaikan dasar argumentasi Imam Syafi'i. Pernikahan Sayidah Aisyah dengan Rasulullah saw, yang diceritakan masih umur 6 tahun, ketika itu Abu Bakar as sebagai wali sayyidah Aisyah. Berdasarkan hadits tersebut, Imam Syafi'i menjelaskan bahwa ayah berhak atas putrinya yang belum baligh. Oleh karena itu wali boleh menikahkan putrinya dengan hak ijbarnya meskipun tanpa harus minta izin dari anaknya. $^{25}$

Menurut Imam Syafi'i, wali merupakan salah satu dari rukun nikah, apabila akad pernikahan tanpa ada wali, maka pernikahan tersebut tidak sah. Adapun dasar hukumnya merujuk pada al-Qur'an, Imam Syafi'I berdasar pada surat al-Baqarah [2]: 232. Ayat ini juga telah menjadi dasar bagi mazhab Hanafi dan mazhab Maliki. Selain itu, Imam Syafi' $i$ juga berdasar kepada Hadits yang sama menjadi dasar bagi mazhab Maliki. Hadits tersebut sebagai berikut:

$$
\begin{array}{r}
\text { (رواه أحمد و أبي بردة أبي موسى عن أبيه رضي الله عنهما قال: قال رسول الله صلى الله عليه وسلم لانكاح إلا بولي اللهائ النسائ وصححه إبن المدنيي والترميذيوابن حبان) }
\end{array}
$$

Artinya: Perkawinan tidak dipandang sah kecuali ada wali.

Pembagian wali dalam Imam Syafi' I ada dua macam:

1. Wali mujbir: seorang yang mempunyai hak penuh untuk mendesak putrinya menikah dengan calon pilihan ayahnya.

2. Wali ikhtiyar: wali yang tidak boleh memaksa putrinya untuk menikah tanpa kerelaan putrinya. Persetujuannya ini tidak cukup diamnya, tapi harus ada pernyataan yang jelas. Wali juga harus dari jalur keturunan laki-laki.

Dalam pandangan imam Syafi'i, perempuan menikah harus melalui walinya dan tidak boleh menikahkan dirinya sendiri.

Pembahasan wali mujbir dalam perspektif Imam Syafi'i adalah:

3. Anak kecil. Perwalian ini dikhususkan kepada anak perempuan (dan laki-laki) yang belum baligh, dan tidak kepada perempuan janda. Pernikahan anak kecil (laki-laki atau perempuan) bisa diwakilkan kepada ayah atau kakeknya, bahkan dengan hak ijbar ini wali nikah berhak menikahkan anak di bawah umur. ${ }^{26}$

\footnotetext{
${ }^{25}$ Zainul Mahmudi, Sosiologi Fikih Perempuan Formulasi Dialektis Fikih Perempuan dengan Kondisi dalam Pandangan Imam Syafi'I, (Malang: Malang Press, 2009), 114

${ }^{26}$ Syafiq Hasyim, Hal-Hal yang Tak Terpikirkan tentang Isu-Isu Keperempuanan dalam Islam, ......155
} 
4. Orang Gila. Sebagaimana dijelaskan di atas bahwa hukum perwalian orang gila sama dengan anak kecil, dan di kalangan ulama mazhab ada kesamaan pendapatnya dalam persoalan ini. Menurut Imam Syafi'i, apabila mereka tidak mempunyai wali $a q r a b$, wali hakim lebih berhak mengawinkan laki-laki dan perempuan gila ini. Pendapat ini berdasarkan hadits: فالشلطان وليٌّ من لا ولي له

5. Orang Idiot. Akad orang idiot dipandang tidak sah kecuali mendapat izin walinya.

6. Orang baligh dan berakal sehat. Jika masih gadis, meskipun sudah berakal sehat, maka walinya lebih berhak. Tetapi bagi janda, wali dilarang memaksanya untuk menikah tanpa ada persetujuannya. Demikian juga janda dilarang menikahkan dirinya sendiri, kecuali mendapat restu dari walinya. Akad perempuan dipandang Imam Syafi'i tidak berlaku.

\section{Pendapat Hambali}

Menurut Mazhab Hambali, bahwa wali merupakan bagian dari syarat sah menikah, apabila tanpa wali maka pernikahan tidak sah. Pendapat tentang hak ijbar wali, berlaku kepada gadis dan janda, bukan hanya kecil, tapi yang dewasa, sehat akalnya atau yang gila. ${ }^{28}$ Perempuan tidak ada hak untuk menikahkan dirinya sendiri. Namun janda tetap dimintai izinnya. Dasar argumentasi mazhab ini adalah:

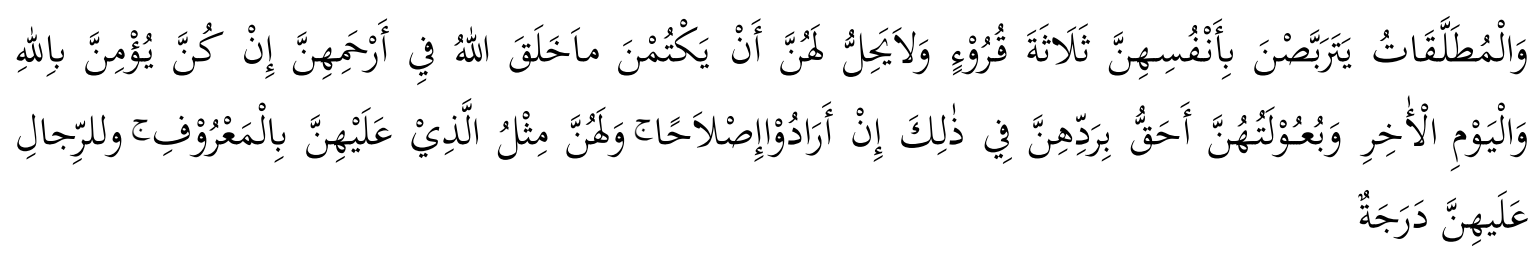

Artinya: Perempuan-perempuan yang ditalak hendaknya menahan diri (menunggu) tiga kali quru' (suci atau haid), tidak boleh menyembunyikan apa yang diciptakan Allah dalam rahimnya. Jika mereka beriman kepada Allah dan hari akhir. Dan suami-suaminya berhak merujukinya dalam masa iddah, jika pada suami menghendaki islah, dan para perempuan mempunyai hak yang seimbang dengan kewajibannya menurut cara yang ma'ruf. Akan tetapi para suami, mempunyai tingkatan satu derajat atas istrinya.' (Q.S. Al-Baqarah [2]: 228)

Dalam surat al-Nur [24]: 22

Artinya: 'Dan janganlah orang-orang yang mempunyai kelebihan dan kelapangan di antara kamu bersumpah bahwa mereka (tidak) akan memberi (bantuan) kepada kaum kerabat(nya) orang-orang yang miskin dan orang-orang yang berhijrah

\footnotetext{
${ }^{27}$ Syaiful Hidayat, Wali Nikah dalam Perspektif Empat Mazhab, ....., 123

${ }^{28}$ Al-Zuhaily, Wahbah, al-Fiqh al-Islam wa Adillatuha, juz VII, 192
} 
pada jalan Allah, dan hendaklah mereka memaafkan dan berlapang dada. Apakah kamu tidak ingin bahwa Allah mengampunimu? Dan Allah adalah Maha Pengampun lagi Maha Penyayang'.

Sedangkan dalil-dalil yang lain, antaranya:

(1) Hadits Nabi saw: Menurut riwayat Ahmad dan lima perawi, dimana Hadits ini juga menjadi dasar hukum bagi mazhab Maliki dan mazhab Syafi'i:

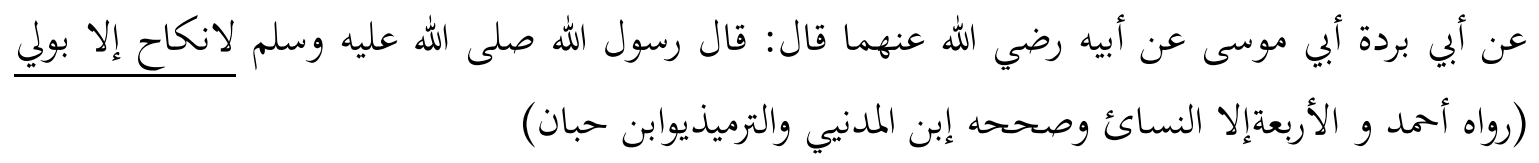

Artinya: Perkawinan tidak dipandang sah kecuali ada wali.

Selain itu, Hadits dari Aisyah juga termasuk dasar argumentasinya, yang artinya:"setiap perempuan yang menikah tanpa izin walinya, maka pernikahannya batal." (H.R. Ahmad, Abu Daud dan Tirmidzi dan lainnya). Termasuk Hadits dari Aisyah berikut ini: إن النكاح مِنْ غَيْرِ وَلِّ بَاطِلِ (sesungguhnya nikah tanpa wali adalah batal).

Adapun hak ijbar wali dalam mazhab ini sebagai berikut:

a. Anak kecil. Wali anak kecil adalah ayahnya dan ibu tidak mempunyai hak perwalian.

b. Orang gila. Para ulama sepakat terkait perwalian orang gila sama dengan anak kecil. Baik gila sejak kecil atau sudah dewasa.

c. Orang idiot (safih). Perwalian orang idiot ada pada hakim, tidak pada ayah atau kakeknya, apalagi dari orang yang menerima wasiat mereka berdua. ${ }^{29}$ Sedangkan akad orang idiot adalah sah dan tidak perlu izin walinya.

d. Putri baligh dan berakal sehat. Di sini ada perbedaan, untuk anak gadis, maka yang menikahkan adalah walinya. Sedang perempuan janda, yang menikahkan adalah walinya atas persetujuannya. Akad perempuan dipandang tidak sah dalam nikah.

\section{Syarat-Syarat Wali Nikah}

Beberapa kitab fiqh telah menjelaskan bahwa syarat-syarat menjadi wali nikah sebagai berikut: ${ }^{30}$

1. Islam. Dasar ketentuan ini adalah surat Ali Imran [3]: 28: Artinya: Janganlah orangorang yang beriman menjadikan orang kafir sebagai teman (pemimpin), melainkan

\footnotetext{
${ }^{29}$ Mughniyah, Muhammad Jawad, Fikih Lima Mazhab, 694

${ }^{30}$ Amir Syarifuddin, Hukum Perkawinan Islam di Indonesia ....
} 
orang-orang yang beriman. Barang siapa yang berbuat demikian, niscaya tidak akan memperoleh apapun dari Allah.

2. Dewasa dan berakal sehat. Dalilnya berdasarkan hadits Nabi saw:

$$
\text { رفع القلم عن ثلاثة عن النائم حتى يستيقظ وعن الصبي حتى يحتلم وعن المجنون حتى يعقل }
$$

Artinya: Diangkat pena (tidak dikenai kewajiban) pada tiga orang ini: orang yang tidur hingga ia bangun, anak kecil hingga berminpin basah, dan orang gila hingga ia berakal.

3. Laki-laki. Meskipun menurut mazhab Hanafi dan Syiah Imamiyah membolehkan perempuan menikahkan dirinya sendiri maupun menikahkan orang lain.

4. Merdeka. Artinya tidak dalam penganpuan.

5. Adil

6. Tidak sedang melakukan ibadah haji atau umrah

\section{Kedudukan Wali Hakim dalam Kitab Fiqh}

Dalam pembahasan wali selain ayah, ada perbedaan pendapat dalam Imam mazhab:

a. Menurut Hanafi, Wali sesudah ayah adalah orang yang menerima wasiat dari ayah. Setelah itu kakek dari ayah, kakek dari ibu tiada hak, atau orang yang menerima wasiat dari kakek.

b. Menurut pandangan mazhab Maliki dan Hambali: orang yang lebih berhak sebagai wali apabila ayah tidak ada orang-orang yang mendapat wasiat. Apabila ayah tidak mewasiati kepada orang lain, perwalian jatuh kepada hakim. Di sini kakek tidak mempunyai hak perwalian.

c. Menurut Imam Syafi'i, apabila pernikahan orang gila tidak mempunyai wali aqrab, maka wali hakim lebih berhak menikahkan mereka. ${ }^{31}$

\section{Kedudukan Wali Nikah dalam Hukum Positif Indonesia}

Hukum perkawinan di Indonesia diatur dalam undang-undang Nomor 1 Tahun 1974 tentang perkawinan. Pasal 2 Undang-undang Nomor 1 tahun 1974 mengatur keabsahan perkawinan didasarkan pada kesesuaian dengan hukum masing-masing agama atau kepercayaan. Bagi orang Islam, maka keabsahan perkawinan merujuk kepada aturan dalam Hukum Islam. Ketentuan tentang perkawinan yang telah dipositivisasikan sejauh ini adalah

\footnotetext{
${ }^{31}$ Syaiful Hidayat, Wali Nikah dalam Perspektif Empat Mazhab, ....., 123
} 
dalam bentuk Kompilasi Hukum Islam (KHI) dan Peraturan perundang-undangan turunan dari Undang-undang Nomor 1 Tahun 1974 diantaranya Peraturan Pemerintah Nomor 9 Tahun 1975, Peraturan Menteri Agama Nomor 11 Tahun 2007 tentang Pencatatan Nikah yang telah dicabut dengan Peraturan Menteri Agama Nomor 19 Tahun 2018 tentang Pencatatan Perkawinan.

KHI mengatur syarat dan rukun perkawinan bagi masyarakat muslim dalam pasal 14, dimana sama dengan ketentuan dalam Peraturan Menteri agama No. 19 Tahun 2018. Pasal 9 ayat (2), yaitu untuk melaksanakan perkawinan harus ada; a) Calon Suami dan calon Isteri; b) Wali nikah; c) Dua orang saksi dan; d) Ijab dan Kabul. Salah satu rukun yang tidak boleh dilewatkan adalah adanya wali nikah. Orang yang berhak menjadi wali nikah bagi seorang perempuan diatur dalam KHI pasal 19-23. ${ }^{32}$

Selanjutnya Pasal 19 KHI mempertegas bahwa wali nikah adalah rukun yang harus dipenuhi bagi calon mempelai perempuan yang bertindak untuk menikahkannya. ${ }^{33}$ Islam mempertegas bahwa wali nikah adalah rukun yang harus dipenuhi bagi calon mempelai perempuan yang bertindak untuk menikahkannya.

Kedudukan wali yang demikian dalam perkawinan menurut Hukum Positif Indoneisa, memberikan akibat hukum tertentu, yakni ketika seorang perempuan tidak memiliki wali atau wali yang berhak sebagaimana diterangkan dalam pasal 21 KHI tidak memenuhi syarat sebagaimana dalam Pasal 20 KHI, yaitu Muslim berakal dan telah baligh, maka yang bertindak sebagai wali dari perempuan tersebut dalam perkawinan adalah wali Hakim. Syarat wali dalam Peraturan Menteri Agama Nomor 19 Tahun 2018 tersebut juga sama dengan ketentuan dalam KHI dimana syarat wali adalah, a) laki-laki; b) beragama Islam; c) baligh; d) berakal; e) adil. ${ }^{34}$ Permen Agama No. 19 tahun 2018 juga menerangkan bahwa wali terdiri dari wali nasab dan wali hakim, apabila wali nasab tidak ada, maka yang bertindak sebagai wali adalah wali hakim.

\section{Wali Hakim dalam Hukum Positif Indonesia}

Menurut Pasal 22 (1) Komplasi Hukum Islam, Hakim dapat bertindak sebagai wali apabila terdapat hal-hal sebagai berikut: ${ }^{35}$

\footnotetext{
${ }^{32}$ Pasal 15 KHI

${ }^{33}$ Pasal 19 KHI

${ }^{34}$ Pasal 9 ayat (2) dan Pasal 11 ayat (2) PMA No 19 Tahun 2018

${ }^{35}$ Pasal 22 (1) Komplasi Hukum Islam (KHI).
} 
a. Apabila wali nasab tidak ada.

b. Tidak mungkin menghadirkannya

c. Wali nasab tidak diketahui keberadaannya

d. Wali adhal

Sedangkan dalam Peraturan Menteri Agama (Permenag) Nomor 19 Tahun 2018. Pasal 12 ayat (3) Wali Hakim ditunjuk menjadi wali untuk seorang perempuan apabila; a) Wali nasab tidak ada; b) Walinya adhal; c) Walinya tidak diketahui keberadaannya; d) walinya tidak dapat dihadirkan karena dalam masa tahanan; atau; e) wali nasab tidak ada yang beragama Islam. Khusus untuk kasus wali adhal harus berdasarkan penetapan tentang adhal-nya wali dari Pengadilan Agama. ${ }^{36}$ Selain itu, hanya orang tertentu saja yang berhak ditunjuk untuk menjadi wali hakim. Permenag Nomor 30 tahun 2005 pasal 3 wali hakim yaitu; Kepala Kator Urusan Agama (KUA), Penghulu Kecamatan atau Pembantu Penghulu bagi daerah yang sulit transportasi dan terpencil. Sedangkan dalam Permenag Nomor 19 tahun 2018, wali Hakim dijabat oleh Kepada KUA Kecamatan sebagaimana ketentuan Pasal 11 ayat (3) Permenag Nomor 19 Tahun 2018. ${ }^{37}$

\section{Analisis Hukum Nikah Perempuan tanpa Wali}

Sebagaimana dijelaskan di depan bahwa hukum perkawinan di Indonesia telah jelas diatur dalam undang-undang Nomor 1 Tahun 1974 tentang perkawinan. Pasal 2 Undangundang Nomor 1 tahun 1974 mengatur keabsahan perkawinan didasarkan pada kesesuaian dengan hukum masing-masing agama atau kepercayaan. Bagi orang Islam, maka keabsahan perkawinan merujuk kepada ketentuan dalam Hukum Islam. Sebagaimana diketahui hampir sebagian besar ulama dalam empat mazhab telah memberikan pendapat, terutama dalam mazhab Maliki, Syafi'I, dan Hambali bahwa wujudnya wali nikah dalam sebuah pernikahan adalah wajib. Baik bagi pasangan yang belum baligh, atau yang sudah baligh dan berakal sehat, atau yang janda. Dalam pandangan ulama mayoritas ini, kehadiran wali bahkan dipandang penting dan menentukan keabsahan sebuah pernikahan, karena wali termasuk dalam syarat-rukun pernikahan. Maka, hukum pernikahan tanpa wali adalah tidak sah. ${ }^{38}$

Sebenarnya tidak ditemukan nas al-Qur'an yang secara tegas dan khusus berbicara terkait wali dalam nikah ini, justru yang banyak ditemukan dengan redaksi yang sedikit

\footnotetext{
${ }^{36}$ Pasal 2 ayat (2) PMA No 2 Tahun 1987 jo Pasal 12 ayat (4) PMA No 19 tahun 2018 jo Pasal 23 ayat (2) KHI

${ }^{37}$ Pasal 11 ayat (3) dan Pasal 12 ayat (1) PMA No 19 Tahun 2018

${ }^{38}$ Ibnu Majah, Sunan Ibn Majah, (Riyad: Dar al-Salam, 2008), no. 1880, 2589
} 
berbeda-beda adalah dari sumber hadits. Dari matan hadits tersebut ada yang mengharuskan ada wali dan ada yang mengharuskan tetap meminta persetujuan perempuan. Sehingga dalam menetapkan hukum wali ini terdapat dua kelompok. Yaitu kelompok mayoritas (Jumhur ulama, bahwa wali merupakan bagian dari syarat dan rukun nikah. Menurut kelompok Jumhur ini, perempuan tidak boleh menikahkan dirinya sendiri, meskipun ia telah dewasa. Kelompok kedua menyatakan, bahwa perempuan yang sudah baligh diperbolehkan menikahkan dirinya sendiri sehingga tanpa walinya, dengan syarat bahwa calon lelakinya sederajat (sekufu). Ini adalah pendapat mazhab Hanafi.

Kebetulan mazhab Syafi'i adalah masuk kelompok mayoritas, atau kelompok pertama, dan telah menetapkan bahwa pernikahan tanpa wali adalah batal. Oleh demikian, produk hukum yang dilahirkan di Indonesia sudah tentu bercorak mazhab Syafi'I ini. Oleh demikian, jika para perempuan meskipun telah dewasa, maka apabila menikah mau tidak mau harus mengukuti ketetapan hukum yang berlaku di Indonesia.

Namun, di era modern ini persoalan wali terkadang menjadi persoalan yang perlu diperhatikan atau mungkin menurut kelompok tertentu perlu ditinjau ulang. Karena pada kenyataannya, di era ini sudah banyak perempuan yang memiliki kecakapan (ahliyyah) yang dapat dikatakan sama dengan lelaki dalam segala bidang. Pendapat ini tentu saja terinspirasi dari pendapat mazhab Hanafi dan Ulama Syiah Imamiyyah yang membolehkan perempuan baligh dan akil untuk menikah tanpa wali. Pendapat ini juga telah berdasar kepada beberapa hadits, antaranya berikut ini: ${ }^{39}$

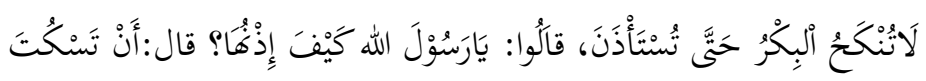

Artinya: Tidak boleh menikahkan anak gadis sehingga ia dimintai izinnya. Para sahabat bertanya: Bagaimana meminta izinnya? Baginda menjawab: Bila ia diam (HR. Bukhârî, Muslim, Tirmîdzi, Ibnu Mâjah dan al-Nasâî).

Namun, menurut penulis, persoalan wali dalam nikah ini tidak dapat dilihat dari sisi sebelah mata hanya karena kemandirian dan kematangan seorang perempuan dalam bidang kehidupan saja. Bagaimana pun memilih jodoh adalah persoalan hati, apabila hati sudah condong ke satu arah, maka segala keburukan akan tidak terlihat olehnya. Semua akan nampak menjadi baik nan indah apabila hati manusia sudah dihinggapi penuh kecintaan.

Di sisi lain, kehadiran seorang wali bukan semata-mata karena persetujuannya, tetapi lebih kepada adab bagaimana anak yang sebelumnya telah menjadi tanggungjawab

\footnotetext{
${ }^{39}$ Al-Jawziyah, Ibn al-Qayyim, Zaad al-Ma'ad,(Beirut: Maktabah al-Manar al-Islamiyah, 1992) juz 5, 90
} 
sepenuhnya ayahnya sejak lahir, kini akan dilepaskan tanggungjawab tersebut kepada orang lain untuk mengembannya. Jadi inilah makna filosofis dari kehadiran dan keridaan seorang ayah ketika harus menikahkan anaknya. Orang tua itu lebih memahami pribadi anaknya, daripada anak itu memahami terhadap dirinya sendiri. Inilah pendapat ijma ulama mengapa wali nikah itu penting dalam sebuah akad pernikahan.

Bahkan dalam perspektif fiqh, ayah ada hak ijbar (berhak memaksa anak gadisnya) jika masih kecil untuk menikah dengan lelaki pilihannya. ${ }^{40} \mathrm{Hal}$ ini karena disamping itu kehadiran wali dalam pernikahan anak perempuannya adalah signifikan dalam fiqh, sehingga suatu pernikahan dipandang tidak sah tanpa kehadiran walinya. Karena kehadiran wali termasuk dalam salah satu syarat, atau ada yang mengatakan bagian dari rukun, pernikahan. Hal ini berdasarkan hadits berikut ini: "Tidak sah pernikahan kecuali dengan wali.,"41

Beberapa fuqaha menjelaskan bahwa terkait persetujuan ayah dalam hal pernikahan seorang anak gadis itu bukan menjadi syarat dalam sebuah pernikahan. Meskipun menurut pendapat kalangan fuqaha', kehadiran ayah dalam pernikahan anak gadis adalah salah satu syarat yang harus dipenuhi. Namun, apabila ayahnya yang masih hidup tidak mau merestuinya dengan tanpa suatu alasan yang dibenarkan, biasanya disebut wali adhal, maka menurut kesepakatan para fuqaha, haknya dicabut. Dalam posisi demikian, maka si gadis bisa sepenuhnya bebas untuk menentukan pilihan calon suaminya dan dapat melanjutkan pernikahannya dengan wali hakim. ${ }^{42}$

\section{Kesimpulan}

Dalam pembahasan wali pernikahan dalam Islam memang terjadi ikhtilaf, sebagaimana yang sudah dijelaskan di atas. Mayoritas ulama telah memberikan pendapat, terutama dalam mazhab Maliki, Syafi'I, dan Hambali bahwa wujudnya wali nikah dalam sebuah pernikahan adalah wajib. Baik bagi pasangan yang belum baligh, atau yang sudah baligh dan berakal sehat, atau yang janda. Dalam pandangan ulama mayoritas ini, kehadiran wali bahkan dipandang penting dan menentukan keabsahan sebuah pernikahan, karena wali termasuk dalam syarat-rukun pernikahan. Maka, apabila pernikahan tanpa wali, hukumnya

\footnotetext{
${ }^{40}$ Al-Syairâzî, Abî Ishâq Ibrâhîm bin cAlî bin Yûsuf al-Fairuzzâbâdî, al-Muhadzdzab fỉ Fiqh al-Imâm al-Syâficî, (Damascus: Dâr al-Qalam, 1992), juz 2, 429-430

${ }^{41}$ HR. Abû Daud no. 2085, Tirmidzi no. 1101, Ibnu Majah no. 1880 dan Ahmad 4:418; shahih; Al-Jaziry, ${ }^{\mathrm{c} A b d}$ al-Rahman, Kitab al-Fiqh Ala al-Madzahib al-Arb ${ }^{c}$ ah....., 46

${ }^{42}$ Al-Zuhaily, Wahbah, al-Fiqh al-Islamy wa Adillatuhu, (Beirut: Dar al-Fikr, 1997), juz 9, 6720
} 
menjadi tidak sah. ${ }^{43}$ Pendapat ini telah berdasarkan kepada dalil-dalil yang otoritatif dalam Islam, baik dari al-Qur'an maupun Hadits. Sedangkan pendapat yang lain telah membolehkan seorang perempuan dewasa dan berakal sehat untuk menikahkan dirinya, asalkan calon suami tersebut sederajat. Pendapat kedua ini dipelopori mazhab Hanafi dan Syiah Imamiyah.

Terkait hukum pernikahan perempuan tanpa wali dalam hukum yang berlaku di Indonesia, adalah tidak sah. Karena produk hukum yang berlaku di Indonesia adalah menganut mazhab Syafi'i. Dengan kehadiran wali dan keridaannya dalam akad pernikahan anaknya ini tentu ada ibrah dan nilai filosofisnya. Dimana seorang ayah akan memasrahkan dan melepaskan tanggungjawabnya kepada lalaki yang menikahi anaknya, supaya ia menjadi lebih tanggungjawab dan melindunginya. Wallahu a'lamu bi al-shawab.

\footnotetext{
${ }^{43}$ Ibnu Majah, Sunan Ibn Majah, (Riyad: Dar al-Salam, 2008), no. 1880, 2589
} 


\section{DAFTAR RUJUKAN}

Al-Qur'an al-Karim

Asqalany, Ibnu Hajar (Al), 1994, Bulûgh al-Maram (Beirut: Dâr al-Fikr)

Ahmad Azhar, 20012, Hukum Perkawinan Islam, (Yogyakarta: UII Press)

Syairâzî, Abî Ishâq Ibrâhîm bin ' ${ }^{c}$ lî bin Yûsuf al-Fairuzzâbâdî (Al), 1992, al-Muhadzdzab fî̀ Fiqh al-Imâm al-Syâfic $\hat{\imath}$, (Damascus: Dâr al-Qalam), juz 2.

Amir syarifuddin, 2014, Hukum Perkawinan Islam di Indonesia, (Jakarta: Kencana)

Departemen Pendidikan Nasional, 2001, Kamus Besar Bahasa Indonesia, (Jakarta: Balai Pustaka), Edisi III.

Ibnu Majah, 2008, Sunan Ibn Majah, (Riyad: Dar al-Salam), no. 1880, 2589

Ismatilah dkk, Makna Wali dan Auliya, 2016, al-Qur'an, Diya' al-Afkar, Vol. 4, no. 02 Desember.

Jawziyah, Ibn al-Qayyim (Al), 1992, Zaad al-Ma'ad,(Beirut: Maktabah al-Manar alIslamiyah) juz 5.

Jaziry, 'Abd al-Rahman (Al), 1990, Kitâb al-fiqh ${ }^{c}$ Alâ al-Madzâhib al-Arbacah (Bairut: Dâr al-Kutub al-Ilmiyah), Jil. 4.

Kompilasi Hukum Islam, 2015, Jakarta: Departemem Agama RI

MAsdar F. Mas’udi, 1997, Islam dan Hak-hak Reproduksi Perempuan (Bandung: Mizan).

Mustafa al-Khin dan Mustafa al-Bugha, 2000, Al-Fiqh al-Manhaji 'ala Mazhab al-Imam alSyafi'I, (Surabaya: Al- Fithrah), Juz IV

Mustafa al-Khin dan Mustafa al-Bugha, 2000, Al-Fiqh al-Manhaji 'ala Mazhab al-Imam alSyafi' I, (Surabaya: Al-Fithrah), Juz IV

Muhammad Jawad Mughniyyah, 2005, Fiqh Lima Mazhab, (Jakarta: Lentera).

Murtada Mutahhari, 2000, Hak-hak Perempuan dalam Islam, (Jakarta: Lentera Basritama), cet ke-6,

Syafiq Hasyim, 2001, Hal-Hal Yang Tak Terpikirkan Tentang Isu- Isu Keperempuanan dalam Islam, (Bandung: Mizan)

Syaiful Hidayat, 2016, Wali Nikah dalam Perspektif Empat Mazhab, Inovatif, vol. 2 no.1, Februari.

Syaibani, Hasan (Al), 2012, Al-Aslu, (Qatar: Awqaf, 2012), juz 10 
Summa, Muhammad A., 2005, Hukum Keluarga Islam di Dunia Islam, (Jakarta: PT Raja Grafindo Persada)

Tihami dan Sohari Sahrani, 2009, Fikih Munakahat: Kajian Fikih Nikah Lengkap. (Jakarta: Rajawali Press)

Zainul Mahmudi, 2009, Sosiologi Fikih Perempuan Formulasi Dialektis Fikih Perempuan dengan Kondisi dalam Pandangan Imam Syafi'I, (Malang: Malang Press)

Zuhaily, Wahbah (Al), 2011, Fiqh Islam wa Adillatuhu, penterj. Abdul Hay al-Kattani dkk., (Jakarta: Gema Insani), juz VII.

Wardatun Nabilah, 2014, Metode Penetapan Hukum Masdar F. Mas'udi dan Syafiq Hasyim tentang Wali Nikah Perempuan, Skripsi IAIN Sunan Ampel Surabaya.

Tafsir al-Kasysyaf, Juz I. Beirut: Dar al-Fikr, 1917. 